35 ling. S.W. and Coley, P.D. 119901 Oikos 58, 369-377

36 Roach, D.A. and Wulff, R.D. (1987) Annu. Rev. Ecol. Syst. 18, 209-235

37 Miao, S.L., Bazzaz, F.A. and Primack, R.B. Ecology (in press)

38 Wulff, R.D. (1986) /. Ecol. 74, 87-97

39 Dorne, A.I. $(1981)$ Can. I. Bot. 59
1893-1901

40 Stratton, D.A. (1989) Am. I. Bot. 76, 1646-1653

41 Miao, S.L., Bazzaz, F.A. and Primack, R.B 11991) Ecology 72, 586-596

42 Barkman, J.J. (1988) in Plant Form and Vegetation Structure (Werger, M.I.A., van der Aart, P.I.M.. During, H.I. and Verhoeven,
I.T.A., edsi, pp. 9-44. SPB Academic

Publishers

43 Raunkier, C. 119341 The Lite Forms of

Plants and Statistical Plant Geography.

Clarendon Press

44 Grime, I.P., Hodyson, I.G. and Hunt, R

I 19881 Comparative Plant Ecology. Unwin Hyman

\title{
Parental Investment Theory: The Role of Past Investment
}

\section{Ronald M. Coleman and Mart R. Gross}

The role of past investment in parental-care behaviour has often been controversial. Some researchers have argued that organisms basing present investment on past investment are committing the 'Concorde fallacy'. Others have incorporated life history theory to suggest that investing according to past investment is one component of investing according to expected future reproductive success: a parent can use past investment as well as other information, such as brood size, to make its optimal parental-investment decisions. Although parental-investment research is still in its infancy, the incorporation of life history theory suggests that the Concorde fallacy is a misleading concept.

A goal of parental-investment research is to understand how organisms decide the quantity of effort they will allocate to the survivorship of their present offspring. Dozens of papers have addressed whether parents should incorporate past investment into their parentalinvestment decisions (see review by Curio' and also Refs 2-12). Some authors have argued that if past investment is used, the organism is committing an error of judgement, called the Concorde fallacy. The purpose of this paper is to help clarify how past investment is incorporated into parental-investment decisions. Life history theory shows that the Concorde fallacy has been a misleading concept for parental investment

\section{What is the Concorde fallacy?}

Trivers $^{13}$ placed parental investment within the context of a cost of

Ronald Coleman and Mart Cross are at the Dept of Zoology, University of Toronto, Toronto, Ontario, Canada M5S IA]. reproduction ${ }^{14}$. He explicitly recognized that investment has a cost and defined parental investment as 'any investment by the parent in an individual offspring that increases the offspring's chance of surviving land hence reproductive successl at the cost of the parent's ability to invest in other offspring'. Trivers emphasized that decisions should be based on minimizing wastage of past investment.

Dawkins and Carlisle ${ }^{15.10}$ first drew the analogy between Trivers' investment model and the British government's investment in the Concorde airliner (see Wilson ${ }^{17}$ ). It seemed that the amount of past investment rather than the probability of $f u-$ ture rewards determined additional government expenditures on Concorde. They, and others ${ }^{18,19}$, argued that a parent's behaviour should be determined by the expected future pay-off rather than by whether past investment would be wasted. The phrase 'commit the concorde fallacy' was coined by Weatherhead ${ }^{21}$ and Dawkins and Brockmann ${ }^{21}$ to describe organisms that behaved in this apparently uneconomical manner.

Surprisingly, while numerous papers refer to the 'Concorde fallacy', there is no explicit definition of it in the research literature ${ }^{22}$. The principle is that an organism should not behave to minimize wastage of past investment, rather it should maximize expected future benefits ${ }^{15.10}$ From this, the Concorde fallacy can be defined as decisions based on past investment patterns rather than expected future benefits Although Dawkins and Carlisle acknowledged that past investment can influence ability to invest in the future, they trivialized this relationship. Their emphasis on future benefits alone led to the working hypothesis: if an organism bases present investment on past investment, then it is committing the Concorde fallacy 21.22

\section{Tests of the Concorde fallacy}

Many researchers have attempted to test the working hypothesis of the Concorde fallacy le.g. Refs 20-251. A typical test would involve manipulating clutch or brood size to uncouple a parent's past investment and expected future benefits (Box 1 ). If the parent's present investment was influenced by its past investment, the researcher concluded that the parent was committing the Concorde fallacy. From these tests, several researchers concluded that organisms do commit the Concorde fallacy. Unfortunately, the working hypothesis of the Cuncorde fallacy is inconsistent with life history theory, making this conclusion inappropriate.

\section{The importance of life history theory in} understanding parental investment

Parental-investment theory has only recently begun to incorporate life history theory ${ }^{26,27}$. Life history theory is concerned with how natural selection optimizes the allocation of resources among competing demands to maximize lifetime reproductive success. Organisms are therefore 'optimal' subject to the constraints across which the optimization process operates ${ }^{28}$. Two major points from life history theory are particularly relevant to the issue of the Concorde fallacy.

First, there is a cost to reproduction; energy allocated to one function, such as reproduction, is not available for use elsewhere ${ }^{14}$. This cost, though often difficult to detect empirically, will be expressed in future reproductive output, through 
either decreased adult survival or lower progeny number or quality 29,30 . The cost of reproduction results in a trade-off between investing in the present and ability to invest in the future. Any change in present investment must therefore change an organism's ability to invest in its future. If past investment is defined as the cumulative sum of investments to the present time, then past investment must also be important in determining an organism's ability to invest in the future. This relationship between past and future investment is an important life history component of parentalinvestment decisions.

Consider the simple case of a parent in a constant environment, with a fixed resource budget to invest during its lifetime. Any increase in past investment must be accompanied by a decrease in resources for future investment. If future reproductive success is determined only by future investment, it follows that making decisions according to past investment must be one component of making decisions according to expected future reproductive success (la) in Box 2). In situations where the total resources for investment change during the life of the organism, future investment continues to be affected by past investment, but to a lesser degree (lb) in Box 21. For example, chance success in foraging might increase the size of the resource budget, and chance failure to find food might cause it to shrink. Similarly, factors other than future investment can influence future reproductive success. For example, changes in the environment that influence offspring survivorship dictate that future reproductive success will no longer be completely determined by future investment $(\mid \mathrm{Cl}$ in Box 2$)$. As more stochastic variables are added, past investment becomes less reliable as the sole predictor of future reproductive success. In the most extreme case, the combination of (b) and $(c)$ in Box 2, past investment may have a small effect on future reproductive success ((d) in Box 2). However, even here, a cause and effect relationship persists between a change in past investment and change in future reproductive success.
Second, an organism that behaves to maximize its remaining lifetime reproductive success at every point in its life will on average maximize its lifetime reproductive success $^{31}$. Remaining lifetime reproductive success can be viewed as having two components: success via the present brood and success via all future broods. Life history theory shows that remaining lifetime reproductive success can only be maximized if a parent invests according to the value of the present brood relative to the value of its expected future broods ${ }^{27}$. But since the value of the parent's expected future broods is also determined by its past investment, organisms may base present investment on past investment. Investing according to past investment is one component of investing according to expected future reproductive success le.g. Ref. 32).

Unfortunately, research on the Concorde fallacy has not incorporated these life history principles. For example, in Box 1, because the females with initial clutches of four eggs (group B) had expended more past investment than females that started with two eggs (group A), their expected futures must be less than females in group A. Even though both groups of parents ended up with two eggs to defend, the relative value of those eggs to group B femalcs was greater than their value to group A females. Therefore, life history theory predicts that females in $B$ will defend more than those in A. Indeed, some studies have found that organisms do respond to past investment as predicted by life history theory ${ }^{33}$.

Since life history theory predicts the same investment decisions as a concordian interpretation, an interesting dilemma arises. The working hypothesis of the Concorde fallacy'if a parent bases present investment on past investment, then it is committing the Concorde fallacy' cannot be correct from a life history perspective. Because investing according to past investment is one component of investing according to expected future reproductive success, organisms basing present investment decisions on past investment are maximizing lifetime reproductive success. They are not making an error based on false
Box 1. Experimental tests of the Concorde fallacy

A

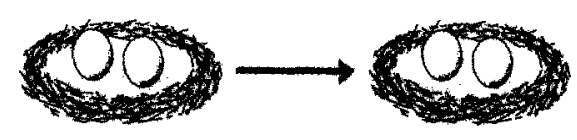

B

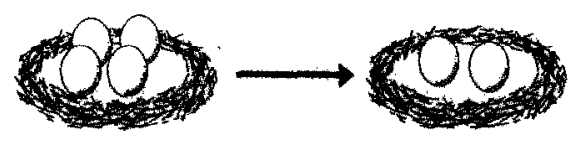

This illustrates an experimental design used to test whether a parent will commit the Concorde fallacy. We assume that parental investment is provided by a female bird. Nests are divided into two types: those with initial clutches of two eggs (A) and those with four eggs (B). Part way through the brood cycle, the experimenter removes two eggs from the four-egg clutches (B). At this point, fermales in $B$ will have expended more parental investment due to the costs of incubation $^{35}$. The willingness of each female to defend its nest is then compared by presenting a dummy egg predator and scoring the female's defensive aggression. According to a concordian interpretation of this experiment, if females in B defend more than those in $A$, they are said to be committing the Concorde fallacy (because they are basing their present investment on their past investment).

Box 2. Possible relationships between past investment (PI), futore investment (F), and future reproductive success (FRS)

(a) No change in resource budget

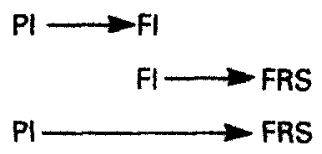

(b) Change in resource budget

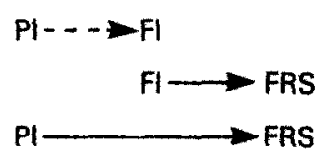

(c) Other factors influence FRS

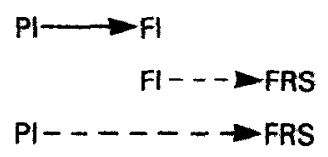

(d) Change in resource budget and other factors influence FRS

$$
\begin{aligned}
& \mathrm{Pl}-\rightarrow \mathrm{FI} \\
& \mathrm{FI}-\rightarrow \text { FRS } \\
& \mathrm{Pl}-\longrightarrow \text { FRS }
\end{aligned}
$$

A solid line means 'completely determines', a narrowly dashed line means 'partially determines', and a widely dashed line means 'weakly determines'. In (a), changes in Pl directly determine changes in FRS. In (b) and (c), changes in PI only partially determine changes in FRS because of the weakened relationship between $\mathrm{PI}$ and $\mathrm{Fl}$, and $\mathrm{Fl}$ and FRS respectively. In (d), changes in PI only weakly determine changes in FRS. 
reasoning (the definition of fallacy ${ }^{34}$ ). Thus it is a misleading conclusion that animals commit the Concorde fallacy.

\section{Cues for determining investment}

There are many cues that organisms may use to determine their optimal current investment. Past investment is only one of these. For example, parents may be able to count their offspring or evaluate their environmental resource base. The use of these cues will depend on their predictive value relative to the costs of developing and maintaining the neurological, physiological and morphological machinery to use them. Unlike many speciesspecific sources of information, the fact that past investment always influences the relative value of the current brood suggests that it will often be involved in the parent's cues for determining investment.

\section{Risk as past investment}

Should past investment involving risk to the parent, the offspring or both influence present investment?

Imagine a nesting male fish defending his brood of young from predators. Suppose that a large predator representing a risk to both the male and his brood approaches the nest. What should the parental male do? If he does nothing, the predator has a probability greater than zero of eating the brood, but zero probability $(p)$ of eating the male. But if the male attempts to defend the nest, either through defensive displays or by attacking the predator, his probability of getting eaten increases $\left(p^{\prime}>0\right)$. Here we have two parental-investment questions. Will the male's decision to defend depend upon the risk to himself relative to the progeny? Second, will the risk to the male influence his future parentalinvestment decisions?

In theory, the male should devalue his willingness to defend his present brood by the currency $p^{\prime}$. This is because $p^{\prime}$ is also a measure of the future young that are potentially forfeited through defense of the present brood. Thus, if $p^{\prime}$ were 0.5 , then 0.5 times the sum of expected future progeny is being invested into the defense of the present young. If the sum of expected future progeny is large, then the willingness to take the risk should be low. More precisely, the relative value of the present brood to future broods should dictate the male's actions ${ }^{26,27}$

If defensive action is taken and the predator is driven away, the risk to both the male and the brood is then over. Will the risk taken by the male influence his subsequent parental-investment decisions? In so far as the energy investment in driving away the present predator reduced future reproductive investment, the risk taken will necessarily influence future parentalinvestment decisions. A second aspect is the non-energetic investment of the risk. We defined this risk as $p^{\prime}$, the potential investment of future progeny into defense of present progeny. However, $p^{\prime}$ did not materialize in our example because the parental male was not eaten. Therefore, after the incident, the risky investment really had only one cost - the direct expenditure of resources. Although $p^{\prime}$ should enter the calculation of whether to take the risk, it should not enter future parental-investment decisions. Risk behaviours, once taken, should influence future parental investment only through the resource cost of the act, not through the risk itself. There is no necessary coupling between a risk investment that has transpired in the past and ability to invest in the future

\section{Conclusion}

The confusion surrounding the role of past investment in parental behaviour has been highlighted by the Concorde fallacy. We show that the working hypothesis of the Concorde fallacy - basing present investment on past investment is fallacious - is not logically consistent with life history theory. Life history theory predicts that past investment as well as other information may be a useful guide to present investment. There is no role for the Concorde fallacy in understanding parental-investment theory.

\section{Acknowledgements}

We thank [. Còté I. Fleming, I. Reynolds and R.C. Sargent for discussion, and E. Curio and D. Westmoreland for comments on the manuscript. RMC was supported by an NSERC of Canada Postgraduate Scholarship, University of Toronto Fellowships and an Ontario Graduate Scholarship. Research costs were met by an NSERC of Canada Operating Crant to MRGi

\section{References}

1 Curio, E. (1987) Trends Ecol. Evol. 2 148-152

2 Knight, R.L. and Temple, S.A. 119861 Auk $103,318-327$

3 Kilpi, M. 11987) Omis Femn. 04, 10-20

4 Armstrong, T. and Robertson, R.I. 119881

Anim. Behav. 30, 941-943

5 Montgomerie, R.D. and Weatherhead, P.I 119881 Q. Rev. Biol. 63, 167-187

6 Westneat, D.F. 119891 Auk 100. 747-749 7 Burger, J.A et al. (1989) Behaviour 1 ।1,

129-143

8 Redondo, T. (1989) Rehaviour 111 $161-195$

9 Ridgway, M.S. 119891 Ethology 80,47-54 10 Westmoreland, D. 119891 Anim. Behav.

$38,1062-1060$

11 Lifjeld, I.T. and Slagsvold, T. 11990

Behav. Ecol. 1, 48-54

12 Wiklund, C.G. $11990 \mid$ Behav. Ecol

Sociobiol. 26, 217-233

13 Trivers, R.L. (1972) in Sexual Selection and the Descent of Man ICampbell. B., ed.I. pp. 136-179. Aldine

14 Williams, G.C. 11966$)$ Am. Nat. 100 687-690

15 Dawkins, R. 114701 The Selfish Gene.

Oxford University Press

16 Dawkins, R. and Carlisle, T $11976 /$ Nature $262,131-133$

17 Wilson. A. 11973) The Concorde Fiasco Penguin Books

18 Boucher, D.H. 119771 Am. Nal. 11 1, $786-788$

19 Maynard Smith. 1.119771 Anim. Behav. 25, $1-9$

20 Weatherhead, P.।.119791 Behav. Ecol. Sociobiol. 5, 373-381

21 Dawkins, R. and Brockmann, H.1.119801 Anim. Behav. 28, 892-896

22 Immelmann, $K$ and Beer, C. 119891 A Dictionary of Ethology. Cambridge University Press

23 Weatherhead, P.I. 11982। 2. Ticrpsychol. 60, 199-208

24 Robertson, R.J. and Biermann, G. C. 114791 Z. Tierpsychol. 50, 124-128

25 Carlisle, T.R. 119851 Anim. Behav. 33 234-238

26 Curio, E., Regalmann, K. and

Zimmermann, U. $(1984)$ Z. Tierpsychol 00 $101-127$

27 Sargent, R.C. and Gross, M.R. $11985 \mid$

Behav. Ecol Sociobiol. 17, 43-45

28 Parker, G.A. and Maynard Smith, I 19901 Nature 348. 27-33

29 Partridge, L. and Harvey. P.H. 119881 Science 241, $1449-1455$

30 Gustafsson. L. and Part. T. 119901 Nature $347,279-281$

31 Goodman, D. $11982+$ Am Nat. 119. 803-823

32 Fagerstrom. T.119821 Oikos 39.116-118 33 Coleman. R.M. Ciross. M.R. and Sargent R.C. (1985) Behav. Ecol. Sociobiol. 18. 59-00 34 Murray, J.A.H., Bradley, H., Craigie. W.A. and Onions. C.T., eds 119781 The Oxford English Dictionary, Oxford University Press

35 Coleman, R.M. and Whittall, R.D. 119881 Behav. Ecol. Sociobiol. 23, 367-372 